\title{
The Role Of Political Parties In Sby's Era Of Leadership Period 2004-2014
}

\author{
Ishaq Rahman ${ }^{1}$, Elyta ${ }^{2}$ \\ 1. Faculty of Social and Political Sciences, Universitas Hasanuddin \\ 2. Faculty of Social and Political Sciences, Universitas Tanjungpura \\ Corresponding Author : ishaq@unhas.ac.id
}

\begin{abstract}
A country that implements the system as mentioned earlier is more towards an authoritarian system of government which aims to dominate and dominate the power of the state towards the people. Democracy cannot survive from such a closed state. In a basic concept of democracy, there is a fundamental principle, namely the principle of sovereignty of the people who run the government.Political communication is one of the many roles played by political parties in various available arrangements. The political party is required to communicate knowledge, issues and political thoughts.Constitutionally, the Government adopts a Presidential System in which the ministers in the cabinet are responsible to the president. But in practice the SBY-JK administration is more of a Parliamentary System.
\end{abstract}

Keywords: political parties, democracy, SBY government

\section{INTRODUCTION}

In the track record of the composition of our state we can see that there are ups and downs in the development of the government system. In fact, a strong country with the support of a strong government but does not provide an opportunity for the public to participate, and does not even involve experts from the legislature or judiciary in the stages of development and democracy, so the title of a democratic country is deemed inappropriate for the country to carry. A country that implements the system as mentioned earlier is more towards an authoritarian system of government which aims to dominate and dominate the power of the state towards the people. Democracy cannot survive from such a closed state.

In a basic concept of 
democracy, there is a fundamental principle, namely the principle of people's sovereignty who runs the government. The application of the principle of people's sovereignty in the sustainability of the government can be reflected in the continuous participation of the community in choosing government policies. The measure of people's sovereignty can be seen from the increase in the number of plays carried out by the people and also the increase in the interests of the people with the policies formed by the government. It is at this point that political parties take up their play, namely as a link between the interests of the people and then form it in a government policy. Although there are several views regarding political parties, there are similarities in these views, namely, political parties have several ideal functions in pursuing the interests of the people through a power race or general election. Several political scholars (Budiarjo, 2008: 405) state that this function consists of the functions of political communication, political socialization, political recruitment and conflict management..Starting from the 19th century, the modern growth of political parties has been known since the 19th century in European and American countries, which coincided with the electoral and parliamentary systems that became known. In gaining power, the meaning of political parties used to be known to organizations or groups. Human organizations that conform to the above characteristics are materially and substantially recognized as political parties (Kantraprawira, 1998: 19).

The increasing number of varieties of new political aspirations in a prison, followed by the need for greater political participation, then jointly participated in the demand for the formation of a number of new channeling institutions, for example the creation of a political party. However, seeing the experience of several countries in other parts of the world the formation of a new party does not carry much function if in practice the party is not new.A party practice can be called strong and adaptative if a party can absorb and blend all the new social forces that arise as an effect of reform. From this 
perspective, party totals will become necessary if the number of parties has an impact on the practical capacity of creating the channeling institutions needed to absorb participation in politics. Form a strong party, must have at least two abilities. The first ability is to pave the way for participation in politics through party channels, until it is able to shift all forms of radical political activity. The second covers and conveys the political participation of several newly directed groups, with the aim of suppressing the pressure handled by the political form.

Based on the description previously stated, the formulation of the problem is "What was the role of political parties in the SBY leadership era for the 2004-2014 period"?

\section{DISCUSSION}

\section{The Role of Political Parties}

Political parties are concerned with what should be done and the consequences it has for the political system. In general, it can be said that political parties have four main functions (Budiarjo, 2008: 163-166). Political parties are concerned with what must be implemented and the impacts they have on political practice. Overall, it can be said that political parties have four core functions (1) Political parties as a means of political communication. Political parties create communication by listening to various opinions of the public regarding what a political practice or government should implement in order to realize the people's needs and desires. The various needs and desires that are controlled by the party by combining them are called interest appregration. Then the output of the combination is then formed in an arrangement called interest appregration. The result of this arrangement is then endeavored by the political parties to become public policy. Apart from that, political parties also have the function of being able to explain to party members all government policies; (2) Political parties as a means of political socialization. In their function, political socialization has the aim of publishing and conveying understanding to the people regarding various norms that are related to political phenomena. Through this process, it is envisioned the emergence of supportive political behavior for the 
political practice to be created; (3) Political parties as a means of political recruitment, In addition, political parties have a recruiting role so that they can maintain the course of life of the related political parties. On this road, candidates who can become party leaders will continually be ready if there is a leadership vacuum or a change in leadership. Only parties that can cadre can maintain the continuity of the party; (4) Parties as a means of managing Conflict, in politics there are always conflicts, as a result of the existence of disimilarity and contradiction regarding the ideals and needs of the social blocs. This disparity must be minimized and the core point is found, then an agreement can be obtained between the community blocks (Budiarjo, 2008: 405). On this road, candidates who can become party leaders will continually be ready if there is a leadership vacuum or a change in leadership. Only parties that can cadre can maintain the continuity of the party; (4) Parties as a means of managing Conflict, in politics there are always conflicts, as a result of the existence of disimilarity and contradiction regarding the ideals and needs of the social blocs. This disparity must be minimized and the core point is found, then an agreement can be obtained between the community blocks (Budiarjo, 2008: 405). On this road, candidates who can become party leaders will continually be ready if there is a leadership vacuum or a change in leadership. Only parties that can cadre can maintain the continuity of the party; (4) Parties as a means of managing Conflict, in politics there are always conflicts, as a result of the existence of disimilarity and contradiction regarding the ideals and needs of the social blocs. This disparity must be minimized and the core point is found, then an agreement can be obtained between the community blocks (Budiarjo, 2008: 405). as a result of the existence of disimilarity and contradiction regarding the ideals and needs of the social blocks. This disparity must be minimized and the core point is found, then an agreement can be obtained between the community blocks (Budiarjo, 2008: 405). as a result of the existence of disimilarity and contradiction regarding the ideals and 
needs of the social blocks. This disparity must be minimized and the core point is found, then an agreement can be obtained between the community blocks (Budiarjo, 2008: 405).

Having a political party representative in a government leads to domination and prioritizing their party is a reality of political practice in the Indonesian State. However, since the reformation was raised, the pressure on democracy, which is also the agenda of reform, has become a natural thing if in the exercise of power residing in political parties it is suspected that it does not represent the will of the common people. Although in the party practice that has been regulated in Law no. 31/2002 concerning Political Parties, provides the opportunity for the birth of a political party which it dreams of being able to connect all the needs of the people it represents. We have actually implemented a multiparty system since the 1999 elections which subsequently emerged, Law no. $12 / 2003$ regarding the elections for DPR, DPD and DPRD and Law no. $22 / 2003$ concerning the Structure of the MPR, DPR, DPD and DPRD.
Especially with the amendment of the 1945 Constitution, a fundamental shift took place in the composition of our state, namely the emergence of a new body, namely the Regional Representative Council (DPD), which was appointed directly by the community to represent regional needs in the ongoing regional autonomy. DPD is the embodiment of individual representatives to take over the seats of Delegates for Regions and Groups in the MPR. In addition, the MPR is no longer the highest state institution since the enactment of Law no. $23 / 2003$ on direct presidential and vice presidential elections. DPD is the embodiment of individual representatives to take over the seats of Delegates for Regions and Groups in the MPR. In addition, the MPR is no longer the highest state institution since the enactment of Law no. $23 / 2003$ on direct presidential and vice presidential elections. DPD is the embodiment of individual representatives to take over the seats of Delegates for Regions and Groups in the MPR. In addition, the MPR is no longer the highest state institution since the enactment of Law no. 
23/2003 on direct presidential and vice presidential elections.

Initially, fair, transparent and democratic political recruitment was aimed at appointing qualified cadres who can work on people's lives so that they can prosper and feel comfortable and safe in life for the Indonesian people. Mistakes in the appointment of representatives to important positions can divert the goals of the struggle from dreams of welfare, prosperity and justice for the wider community. On the other hand, political parties participate in carrying out their function to realize the pulse of democracy, especially because political parties are transformed into a communication facility between elements of society and the state. On the other hand, as people's lives grew, political parties were also being pressured to become more present and have more weight. Through political parties, the people can realize their right to express their opinions regarding the purpose of life and future thoughts in social and state life. Political parties are an indispensable part of the practice of democratic politics.
The composition of the party has referred to the principles of people's sovereignty. Namely conveying freedom, equality, and togetherness. Political parties can depict important plays in the ranks of creating freedom, equality and togetherness in an effort to create a united nation and state. The path to political life that contributes plays to political parties as national assets is carried out in accordance with the principles of change and linkages which increasingly create maturity and responsibility in democracy.

\section{The Role of Political Parties in SBY's Leadership Era 2004-2014}

Political parties are one of the political infrastructure groups in human organizations for a purpose, ideology, political platform programs, and activity plans to be more pragmatic according to the short-term to long-term sequence and have criteria for power. Thus, each organization according to the above characteristics is recognized as a political party (Surbakti, 2003). In carrying out the wheels of government, the United Indonesia Cabinet volume I and volume IIneed a way of political communication. Political communication is one of the 
many roles played by political parties in the various available arrangements. The political party is required to communicate knowledge, issues and political thoughts. The mass media here takes many functions as a means of political communication and creates a political culture. With the aim that all cadres in the party can recognize party principles, the work program includes all the ideas of the party with the aim of building a moral bond with the party. Political communication like this makes use of the party media itself or the mass media that supports it.

The political movement in 2005 underlined that political parties were not ready for this awkward practice. This is because political parties depend on one role, namely the recruitment of political elites. Other functions related to the readiness of candidates in carrying out their duties if elected in the election are forgotten. Political parties are focused on trying to take over authority, but do not understand why this authority is given to them within a predetermined period of time (five years). If political parties cannot work on and deeply do not change themselves by choosing leaders properly through democratic policies, the people will no longer support them.

The facts that have been described can be accepted if the community always wants changes to a better goal, but if there is a lack of trust in political parties which results in the emergence of vested interest groups that are deemed not represented, then press as appropriate for gender until policies appear passed without furthermore the gender concerned undertakes itself. This has certainly experienced regression in establishing political and democratic practices in Indonesia. This is because it has been regulated in the 1945 Constitution prior to the amendment, namely the presence of regional representatives and blocks through appointment without being elected, then it is deemed undemocratic and even feels that it does not represent the region and its group.

Judging from this political reality, in terms of structure the government is practicing the Presidential System in which the ministers in the cabinet have direct responsibility to the president. 
However, if seen in the implementation, the SBY and JK governments refer more to the parliamentary system in which the United Indonesia Cabinet is a coalition Cabinet like a coalition of political parties, even though in fact the cabinet is the authority of the president. When major parties such as Golkar and PDIP, as the winning parties in the first and second elections and most of them in the Legislature, say they are opposition parties. Meanwhile, the presence of the opposition in the Legislative is visible from the parliamentary system, so that it gives the impression of choosing the middle path in the hope that there is a balance between the executive and legislative.

But the push was not strong enough in the legislature, because SBY, who was promoted by the Democratic Party, which was the new party, was not the party that won a place in the legislative parliamentary elections. This political situation actually shows that there were political disturbances at the beginning of the SBY and JK administrations, if there was no change in the political constellation in the Legislature. Not a few policies from SBY \& JK have not worked, in other words, many bills have stopped at the discussion level in the DPR. This is what happened at the regional stage where the elected Regional Heads did not come from large political parties in the regions, for example the Pilkada Tuban, Ngawi, and finally in Bojonegoro, East Java and covering other regions in Indonesia.

The change in the political situation occurred when JK as the vice president at that time was not a representative of a political party in the MUNAS of the Golkar party was elected as the general chairman, so that the Golkar party which was the majority party in the DPR shifted to a supporting political party in the SBY \& JK government. The risk is to clearly divide the functions, roles and powers between the president and the vice president. However, it cannot be guaranteed that the government can be organized if the president and vice president are the result of a coalition which at certain points has other political interests. Appointment and dismissal of ministers in the cabinet, such as the case of the reshuffle of 
yusril (former secretary of state), a cadre of a political party who was in parliament to question comments made by the political party that supported SBY

The non-determination of the basic principles used as the basic foundation of the 1945 Constitution after being amended) in creating our system of government, has provided space for the Executive and legislature to control each other for their respective political interests.The practice of democracy with the aim of realizing power in the hands of the people on a populist basis led by wisdom in representative deliberations is important to be implemented by the People's Consultative Assembly, the People's Representative Council and the Regional Representative Council which are envisioned to absorb the hopes of all people in the region as well as to build a Presidential institution that can realize and increasing the level of people's welfare in the economy with the help of the people's involvement as well as avoiding the emergence of authoritarian leaders, both individuals, parties and the military.
Therefore, it is envisioned to create a balance between both the executive and legislative institutions, so that no one has greater control over each other. The intended direction is to create economic and political stability, so as to create a dynamic, democratic, prosperous, just and prosperous society. But if we look at the application of governmental practices, we are still struggling to determine the form and it seems that it is the habit of our political elites if we do not want to be called inconsistently and indecisively. The shortcomings of the SBY-JK administration immediately stated that the two of them did not see national political arrangements, which could be seen from the membership structure in the DPR. The problem is, the president does not have the authority in the DPR so he cannot act decisively under pressure from political parties. Apart from that, the appearance of the Minister's work was far from the aspirations of the people. Full of views on the division of authority within his government. A view that likens every step of government policy to be in accordance with the political setting played by 
upper-class political parties or political parties that have higher ties to the government

The pressure to change the cabinet arrangement was unavoidable. Akiba is tied to political accommodation rather than government efficiency. The effect is from the government side, the SBY-JK administration seems to be running in place. From this change in cabinet composition it can be estimated that the beneficiary is the Golkar Party. There are 3 out of 6 ministers who were replaced in the cabinet. And all three are officials from the Golkar party. The cadres are Aburizal Bakrie who was transferred from the Coordinating Minister for the Economy to the Coordinating Minister for People's Welfare, Fahmi Idris who was assigned as Minister of Industry, and Easter Suzetta who was positioned as Minister for National Development Planning.

\section{CONCLUSION}

Constitutionally, the Government adopts a Presidential System in which the ministers in the cabinet are responsible to the president. But in

practice, SBY-JK is more of a Parliamentary System. Where the United Indonesia Cabinet is basically a coalition cabinet that is reflected in a coalition of political parties. in fact the Golkar and PDI-P parties declared themselves to be opposition parties. Even though the existence of this opposition party reflects the parliamentary system. The shortcomings of the SBY-JK administration are interpreted as the fault of SBY-JK itself because they do not see the national political configuration, seen from the composition of membership in the DPR. What is troublesome is that the president does not have power in the DPR so he cannot act decisively against pressure from political parties. In addition, the performance of the ministers is far from the expectations of the people. Golkar's victory further strengthens the sectarian political pattern that exists in our country. The success of Golkar can influence the government, this can lead to political jealousy from other political parties.

\section{Suggestion}


Based on the problems and discussion described by the author, the authors provide suggestions, namely the role of political parties, especially election winners, not to control the president but as political communication and a means for the community to express the opinions and desires of the community.

\section{BIBLIOGRAPHY}

Budiardjo, M. (2008). 2008. DasarDasar Ilmu Politik. Jakarta: PT Gramedia Pustaka Utama.

Kantaprawira, R. (1998). Sistem Politik Indonesia Suatu Model Pengantar,Bandung : CV Sinar Baru.

Surbakti, R. (2003). Memahami Ilmu Politik, Jakarta: PT Gramedia Widiasarana Indonesia. 